number of molecules in such a unit, when the relationship $\rho=n M / V$ enables us to calculate $M$ (the mass of the individual molecule or the molecular weight $\times$ the mass of an atom of hydrogen); $n$ is, of course, a whole number which is dependent on the arrangement of the molecules in the unit cell and can be readily ascertained by a preliminary calculation. The order of accuracy attainable is such that even the number of hydrogen atoms, always an uncertain figure when dealing with large molecules, can be determined; Mr. Riley showed how the new method has been applied to such compounds as the esters of $\alpha$-tocopherol.

The application of monomolecular films in solving constitutional problems was discussed by Dr. J. Schulman in the absence of Dr. E. Stenhagen. $\mathrm{He}$ referred to the new method of Langmuir and Blodgett, which consists in spreading a monomolecular film on water and, by alternately dipping and withdrawing a metal plate, depositing successive 'monolayers' on the metal surface, thus enabling their thickness to be measured by an optical method. From the surface potential and apparent dipole moment measurements it is possible to draw conclusions about the nature and position of the polar groups in the molecule. The area occupied on water gives a measure of the cross-section of the molecule and it is often possible to make deductions as to the shape of the molecule, such as the extent to which a long chain is branched, which would only be possible as the result of elaborate degradation experiments. This was particularly well exemplified by the recent beautiful work on phtoic acid, a toxin derived from the tuberculosis bacillus; the results provide a starting-point for synthetic work in conjunction with biological tests.
Chromatographic adsorption, which was discussed by Dr. A. H. Cook, was discovered by Tswett so long ago as 1906, but its usefulness was not appreciated until it was recently reintroduced by Kuhn, Winterstein and many other workers for the separation of carotenoids. It is essentially a preparative method and its vast scope is only just being realized. In principle it depends on the fact that many substances of comparable solubility in a given solvent differ greatly in their capacity for being adsorbed on a variety of inert materials such as alumina. When a solution containing such substances is allowed to run through a column of the adsorbent, the most readily adsorbed substance is retained nearest the top and the least readily adsorbed is found at the bottom or goes right through. With coloured compounds, such as carotenoids, it is easy to observe the process of adsorption, since rings or zones of colour are produced; the adsorbed substances can then be eluted by changing the solvent or by cutting the column up into sections and extracting each separately. The adsorption of colourless compounds can sometimes be followed by means of ultra-violet light or the zones can be made visible by adding a coloured 'indicator'-a dye of the same degree of adsorbability as the required substance. This ingenious variant of the method was used by Brockmann in the isolation of vitamin $D_{3}$ from fish liver oils. The chromatographic method is also extremely useful for the purification of countless organic compounds and has the advantage that practically no material is lost; it can be used on an almost microscopic scale, as in Schöpf's isolation of the colouring matter of butterflies' wings, or adapted to large-scale work.

G. A. R. KoN.

\title{
Steel Castings
}

\begin{abstract}
A SESSION of the adjourned Autumn Meeting of the Iron and Steel Institute was devoted to a consideration of the extremely important third report of the Steel Castings Research Committee.

After a short introduction, Section 2 deals with the fluidity of iron-carbon and alloy steels, by Prof. J. H. Andrew, G. T. C. Bottomley, W. R. Maddocks and R. T. Percival ; together with other contributions on the Ruff test by T. R. Walker and R. J. Sarjant and T. H. Middleham. The fluidity tests earried out with the standard spiral mould described in the second report of the Committee have been extended and it is evident that in this type of test temperature is the all-important factor, composition itself playing a minor part. An outstanding feature of this paper is the serious attempt made to correlate fluidity with the liquidus and solidus curves. In the Ruff test, where the test piece is a straight rod, there are certain points of difference. As an example, the markedly greater fluidity of Swedish charcoal iron as compared with that of Armeo iron of similar composition, indicates strongly that the difference in oxidation of the melt is a by no means unimportant factor. The influence of oxygen is also shown in the erratic results which are obtained when deoxidants, such for instance as aluminium, are added to the steel. Trials of the test have also been carried out on an industrial scale in a large steel foundry, the results indicating that this method of measuring
\end{abstract}

fluidity gives reproducible results which are sufficiently accurate for practical purposes.

Section 3 deals with a report by Martin Alexander on copper-containing steel castings. The effect of 1 per cent of copper has been investigated in cast steels of widely different composition. The results indicate that this metal is a valuable alloying element in such materials. It improves the mechanical properties of the annealed steel and renders the castings susceptible to a hardening treatment which can be carried out at a temperature below the critical range without distortion or the setting up of internal stress. The full effect of the temper-hardening treatment, however, cannot be employed with advantage on account of the accompanying embrittlement. To avoid the undue fall in impact strength it is necessary to provide a sufficiently tough matrix by keeping the carbon content low and to re-heat the casting to a temperature higher than that giving maximum hardness in order to cause some coalescence of the precipitated constituent.

Section 4 is concerned with the strength and ductility of east steel during cooling in sand moulds from the liquid state. The author, H. F. Hall, has devised a most ingenious, and apparently successful means of determining the susceptibility of the material to give contraction cracks. The test piece is so designed that at some position within it the temperature during cooling is maintained above that of the remainder of 
the bar, while a tension is induced at an early stage by the special design of the end conditions.

Section 5, which represents the first report of the Moulding Materials Sub-Committeo and extends to something like 120 pages, is a remarkable achievement for the time this Committee has been at work, and certainly represents the most important contribution yet made to the scientific and technological study of moulding sands for steel castings.

The report ends with a bibliography of some ninety pages dealing with the manufacture, properties and testing of steel castings, prepared by the Library and Information Department of the Institute. To all who have been in any way concerned with the work for, and the preparation of this report, wholehearted congratulations may be offered.

\section{Economic Policy in the Twentieth Century}

\begin{abstract}
A BROADSHEET, "Twentieth Century Economic A Policy", recently issued by P E P (Political and Economic Planning), directs attention to the need for guiding patterns to replace the one-sided patterns of laissez-faire and nationalism. The broadsheet largely summarizes the attempt to provide the essentials of such a pattern which are set forth in a memorandum prepared by Prof. N. F. Hall, director of the National Institute of Economic and Social Research. Measures adopted to maintain the volume of employment have checked improvements in the standard of living and new policies are required to raise the several national standards of living without in the process setting up intolerable strains. Recent scientific advances, moreover, justify the assumption that there is a minimum physiological standard of living which can be roughly measured and which is a necessary condition of progress in other directions. The satisfaction of minimum physiological neods can be set as an immediate goal for economic policies without sacrificing other values provided the methods adopted do not infringe individual freedom.
\end{abstract}

Economic adjustment demands increasing efficioncy in the older lines of production to liberate resources and particularly labour for new enterprises. The standards now available for nutrition supply a definite basis for assessing advances and setbacks as regards food. Less exactly approximate minimum standards can be ascertained for clothing, house space, and oquipment necessary for physiological well-being under different conditions of climate, etc. The first step towards stable national and international progress is therefore to draw up common standards of a broad and simple character and survey the deficiencies of different countries and regions. Not only is it becoming possible to determine such ininimum standards but also to forecast the actual demand for the various products in given conditions of price, income and knowledge. The key to expansion of demand lies in the relation between money incomes of consumers and the unit prices of basic necessities, which determine how much purchasing power will be available to raise consumption of all classes of goods above the level necessary for mere survival.

The cardinal aim of economic policy should thus be to reduce costs and prices of necessities, setting free margins of purchasing power which will in turn lead to reductions in the price of semi-luxuries.

\section{Science News a Century Ago}

The Statistical Society and Vital Statistics

IN the annual report of the Council of the Statistical Socisty, read at the anniversary myeting on March 15, 1839, it was stated that the Committee on Vital Statistics was still engaged in collecting data from which may be deduced the laws of human mortality. With regard to a collection of the experience of the numerous insurance societies, the circulation of the Committee's forms among the several offices had had the effect of inducing a committee of actuaries to renew the prosecution of a previously contemplated plan for collecting the desired information. Such a committee obviously possesses peculiar facilities for the task, the roport said, and as the Council had recoived the strongest assurance that the actuaries had the same object in view as the Society, to which they had promised to communicate the results of their labours, the proposed inquiry had been abandoned. But the Council had received some valuable returns from various medical establishments in reference to the subject, and the forms of registry suggested by the Council had been adopted in important public institutions.

\section{Stephen Peter Rigaud, F.R.S.}

ON March 16, 1839, the Oxford astronomer Stephen Peter Rigaud died at the house of his friend Benjamin Lewis Vulliamy, the clockmaker, in Pall Mall, Isondon. Descended from a family of French Protestant refugees, he was born in Richmond, Surrey, on August 12, 1774, his father being Stephen Rigaud (d. 1814), who for many years assisted the Rev. Stephen Demainbray at the King's Observatory at Kew. In 1791, at the age of seventeen years, Rigaud entered Exeter College, Oxford, and he spent practically all the rest of his life at the University. Graduating in 1797, ho became a fellow of the College, a tutor and examiner. In 1810 he succeeded Abraham Robertson in the Savilian chair of geo. motry and was again Robertson's successor in 1827 in the Savilian chair of astronomy, and this he held until his death. Described as "a laborious student, widely read, no mean conversationalist and a copious correspondent", he is remembered for his work as a mathematical antiquary and bibliographer.

\section{The Polypi of the Mediterranean}

"THE observations of M. Milne-Edwards on the Polypi of the Mediterranean," said the Athenceum of March 16, 1839, "have induced him to conclude, that the horny cartilaginous or calcareous coverings which envelope them, far from being mere external crusts, without any organic connexion with the animals, which produce them, aro integrant parts of these beings, and consist of an organised tissue, the substance of which is mors or less charged with horny or calcaroous matter deposited in it; and the nutrition of which is effected by introsusception. Among all these animals there exists a tendency in their tegumentary and reproductive parts to become hard, and the degree of solidification which these parts attain is the only character by which zoologists can class them, as naked polypi, flexible polypi, etc."

Prof. Henri Milne-Edwards (1800-1885), who was the son of an Englishman, filled the chairs of entomology, zoology and physiology at the Jardin des Plantes, Paris. 